\title{
Pedagojik Formasyon Eğitimi Alan Matematik Bölümü Öğrencilerinin Problem Kurma Becerilerinin İncelenmesi
}

\author{
Tuba AYDOĞDU İSKENDEROĞLU* Gönül GÜNEŞ**
}

Öz

Çalışmanın amacı; pedagojik formasyon eğitimi alan matematik bölümü öğrencilerinin problem kurma becerilerinin incelenmesidir. Araştırma betimsel bir yaklaşımla özel durum çalışması yöntemi ile yürütülmüştür. Çalışma grubunu, Doğu Karadeniz Bölgesindeki eğitim fakültelerinden birinde pedagojik formasyon eğitimi alan 46 matematik öğrencisi oluşturmaktadır. Veriler, Korkmaz ve Gür (2006) tarafından geliştirilen “Matematik Öğretimi ve Problem Kurma” testi ile elde edilmiştir. Elde edilen veriler, içerik analizine tabi tutulmuş ve "problem", "problem değil" ve "boş" şeklinde temalar oluşturulmuştur. Araştırmada öğrencilerin, farklı içeriklerde sunulan 4 farklı problem durumundan bazılarında (2 ve 3 . durum) daha kolay problem kurabildikleri, diğer bazılarında (1 ve 4 . durum) problem kurmakta daha çok zorlandıkları bulunmuştur. Araştırmanın sonucunda; öğrencilerin çoğunun verilen sayı ve işlemlerin yanı sıra matematiksel eşitlikleri kullanarak problem kurmada daha başarılı oldukları ortaya çıkmıştır. Araştırmanın sonuçlarına bağlı olarak; öğrencilerin pedagojik formasyonda aldıkları alan eğitimi derslerinin yanı sıra problem kurma becerisi kazandıracak derslerin eklenmesi ve formasyon eğitimi süresinin uzatılması önerilmektedir.

Anahtar Kelimeler: Pedagojik formasyon, matematik bölümü öğrencileri, problem kurma becerisi, matematik öğretmeni yetiştirme.

\section{Review of Problem Posing Skills of Undergraduate Mathematics Students Who Receive Pedagogical Formation Training}

\begin{abstract}
This study aims to analyze the problem posing skills among mathematics department students who receive pedagogical formation training. The study was carried out employing a case study methodology, with a descriptive perspective. The participants comprise 46 mathematics department students who receive pedagogical formation training at a respected faculty of education. The
\end{abstract}

\footnotetext{
* Yrd. Doç. Dr., Karadeniz Teknik Üniversitesi, Fatih Eğitim Fakültesi, İlköğretim Bölümü, tiskenderoglu@ktu.edu.tr

** Yrd. Doç. Dr., Karadeniz Teknik Üniversitesi, Fatih Eğitim Fakültesi, İlköğretim Bölümü, gmgunes@ktu.edu.tr
} 
data was gathered using "Mathematics Teaching and Problem Posing" test developed by Korkmaz and Gür (2006). The data underwent content analysis, and were assigned flags of 'problem', 'not a problem', 'no answer' accordingly, upon the review of each problem posed by the participants. The students were able to pose problems relatively easily for some of the 4 cases, while for others, they experienced significant difficulties. These findings may lead to a recommendation to add new courses to the pedagogical formation training programs in order to provide the required skills, and to extend the length of the formation training accordingly.

Keywords: Pedagogical formation; undergraduate mathematics students; problem posing skills, mathematics teacher education.

\section{GİRIŞ}

Problem çözme ve problem kurma becerisi, bütün dünyada olduğu gibi (Chen, Dooren, Chen, ve Verschaffel, 2011; Abramovich, 2014) Türkiye'de de matematik öğretim programlarının ilköğretimden yükseköğrenime kadar en temel becerileri (MEB, 2005, 2013a, 2013b) arasındadır. Özellikle 2004 yılı sonrası hazırlanan matematik öğretimi programlarının genel felsefesi ve vizyonu, 1960 ve 1970'li yıllarda geliştirilen ve 1990'li yılların başına kadar uygulanan programlardan oldukça farklıdır (Ersoy, 2004). Yeni ilköğretim ve ortaöğretim programlarında problem kurma-çözme yaklaşımlı matematik öğretme-öğrenme faaliyetlerine önem verilmiştir (Ersoy, 2004; MEB, 2005, 2013a, 2013b). Öğretim programlarının değiştirilmesiyle sorgulayan, araştıran, eleştirel düşünen, soru soran, iletişimde matematik dilini kullanan ve problemlerin üstesinden gelen bireylerin yetiştirilmesi hedeflenmiştir.

Problem, günlük hayatta insana sıkıntı veren, çözülmesi gereken durum anlamında kullanılmaktadır. Problem, daha önce karşılaşılmayan bir zorluk, aşılması gereken alışılagelmedik bir engel olarak tanımlanabilir (MEB, 2013b). Bu engellerin kaldırılması daha kaliteli yaşam sürdürülmesi için özel önem taşımaktadır. Çeşitli stratejiler arasından seçim yaparak engellerin kaldırılmasında problem çözme becerisi işin içine girer. Problem çözme, bir sorunu çözmek için önceki yaşantılar aracılığıyla öğrenilen kuralların basit biçimde uygulanmasının ötesine giderek yeni çözüm yolları bulabilme olarak da tanımlanabilir (Korkut, 2002). Matematiksel anlamda bakıldığında problem çözme, öğrenenin verilen bir bilgiden matematiksel bir yapı oluşturmasının yanında tek doğru cevaba ulaşmasını içermektedir ve problem çözme bir kavrama işidir. Öğrencinin problem çözme becerisinin geliştirilebilmesi için problem kurma becerisinin gelişmiş olması gerekir (Turhan ve Güven, 2014). Problem kurma, verilen bir durum hakkında incelenecek veya keşfedilecek soruları ve yeni problemler üretmeyi içerir (Akay, 2006). Bu bağlamda problem kurma becerisine sahip bireyler var olan bilgilerini kullanarak yeni bilgiler üretebilir ve kendi problemlerini yaratabilirler (Turhan ve Güven, 2014). Ayrica Gonzales (1998) problem kurmayı, problem çözme basamaklarının beşinci ve son adımı olarak tanımlamaktadır. Pek çok çalışmada (Akay, Soybaş ve Argün, 2006; Toluk- Uçar, 2009; Cankoy ve Darbaz, 2010; Kılıç, 2013; Turhan ve Güven, 2014; Kojima, Miwa ve Matsui, 2015) problem kurma etkinliklerinin öğrencilerin gelişimlerine önemli katkılar sağladığı vurgulanmaktadır. Problem kurma çalışmaları, öğrencilerin niteliksel akıl yürütme becerilerini geliştirmeye ve buna bağlı olarak da problemi anlama başarılarını üst düzeye çıkarmaya, problem çözme becerilerini geliştirmeye (Cankoy ve Darbaz, 2010), matematik kavramlarını anlamaya, farklı ve esnek düşünebilmeye, öğretmen ve öğrencilerin kavram yanılgılarını ortaya çıkarmaya ve öğrencilerin matematik tutum ve inançlarını geliştirmeye (Kojima, Miwa ve Matsui, 2015) yardımcı olur. Bununla birlikte matematiksel 
muhakemeyi öğretme, matematiksel durumları keşfetme ve matematiksel durumları uygun bir şekilde sözlü veya yazılı olarak ifade edebilme özelliklerinin de kazanılmasını sağlar (Akay, Soybaş ve Argün, 2006). Dolayısıyla problem kurma becerisini kazandırmak amaciyla öğretmenler tarafından uygun öğrenme-öğretme süreçlerinin tasarlanması özel önem taşımaktadir.

Ortaöğretim matematik dersi öğretim programının geliştirmeyi hedeflediği matematiksel beceri ve yeterliliklerin başında problem çözme becerisi yer almaktadır. Öğretim programında öğrencilerin problem çözme yeterliliklerinin “problemi anlama, çözümü planlama, planı ve stratejiyi uygulama, çözümün doğruluğunu ve geçerliğini kontrol etme, çözümü genelleme ve yeni/özgün problem kurma" aşamalarıyla ilişkilendirilerek geliştirilmesi önerilmektedir. $\mathrm{Bu}$ aşamalar doğrusal değil döngüsel işleyişe sahiptir (MEB, 2013b). Öğrenciler bir problemin çözümü ile yeni bir problem oluşturabilecek yeterliğe sahip olmalıdırlar. Problem kurma aşaması matematik dersi öğretim programında öğrenci davranışları göz önünde bulundurularak şu şekilde açıklanmıştır.

- Verilen resim, şekil, fotoğraf, harita vb. görsellere uygun gerçekçi problem durumları oluşturma

- Verilen bir gerçek hayat durumuna uygun matematiksel problemleri (veya problemin ne olduğunu) tanımlama

- Belirli bir veri setine uygun gerçekçi problem durumları oluşturma

- Verilen matematiksel işlemlere uygun gerçek/gerçekçi problem durumları oluşturma

- Eldeki bilgilere uygun yeni/özgün problem durumları oluşturma

Problem kurma aşamasında öğrencilere yukarda belirtilen davranışların kazandırılabilmesi için öncelikle matematik öğretmenlerinin bu davranışlara sahip olması beklenir. Yapılan bu çalışma ile pedagojik formasyon eğitimi alan ve öğretmen olabilme sertifikası verilen matematik öğrencilerinin problem kurma becerileri incelenmesiyle elde edilen sonuçlar alan yazına katkı sağlayacaktır.

Alan yazın incelendiğinde, problem kurma becerisini içeren birçok çalışmanın yapılmış olduğu görülmektedir. Özellikle sınıf öğretmeni adayları (Korkmaz ve Gür, 2006; Toluk-Uçar, 2009; Işık ve Kar, 2012; Kılıç, 2013), matematik öğretmeni adayları (Dede ve Yaman, 2005; Korkmaz ve Gür, 2006; Işık, Işık ve Kar, 2011; Kırnap-Dönmez, 2014), matematik öğretmenleri (Kılıç ve İncikabı, 2013), sınıf öğretmenleri (Akay, Soybaş ve Argün, 2006; Kılıç, 2014), ilkokul (Cankoy ve Darbaz, 2010), ortaokul (Bunar, 2011; Turhan, 2011; Işık, Çiltaş ve Kar, 2012; Turhan ve Güven, 2014; Tertemiz ve Sulak, 2013; Arıkan ve Ünal, 2015) ve lise (Demir, 2005) öğrencileri ile yürütülmüş birçok araştırma mevcuttur. Bunların yanı sıra Kılıç (2011) yaptığı çalışmada, İlköğretim Matematik Dersi (1-5 sinıflar) öğretim programında problem kurma becerilerine nasıl yer verildiğini incelemiştir. Görüldüğü gibi problem kurma becerilerine yönelik alan yazında pek çok çalışma ile karşılaşılmakta ancak pedagojik formasyon eğitimi alan öğrencilerle yapılmış bir çalışmaya rastlanmamaktadır. Öğretmenlik sertifikasını alan gelecekte öğretmen olma ihtimali bulunan Fen Fakültesi veya FenEdebiyat Fakültesi mezunu ya da öğrencilerinin bu becerilerinin ortaya konulması ise bir ihtiyacı giderecektir.

Aynı zamanda matematik dersi öğretim programlarının uygulanmasından birinci derecede sorumlu kişi, matematik öğretmenidir. Öğretmenlerden, öğrencilerine öğretim programı kapsamında gerçek yaşamda karşılaşabilecekleri olası problemlerin üstesinden gelme beceri- 
si kazandırmaları beklenmektedir. Öğrenci başarısı ile öğretmen niteliği arasında doğrudan bir ilişkinin söz konusu olduğu bilinmektedir (Sünbül, 1996; Ball, Lubienski ve Mewborn, 2001; Dursun ve Dede, 2004; Ball, Thames ve Phelps, 2008; Savaş, Taş ve Duru, 2010). Ancak matematik öğretiminin kalitesini, öğrenci başarısını arttırmak için şüphesiz öğretmenlerin alan bilgilerinin gerekli olmasına karşın yeterli değildir. Kişinin kendi kendine bir işlemi hesaplayabilmesi, öğrencilerin öğrenmesine katkı sağlayacak mantıksal açıklamalar yapabilmesi için yetersizdir (Ball, 2003; Akt. Kar, 2014). Dolayısıyla öğretmen eğitiminde alan eğitimi önemli bir yere sahiptir. Matematik öğretmeni yetiştirme sürecinde öğretmen adaylarına eğitimleri boyunca problem kurma, problemi yeniden düzenleme gibi becerilerinde geliştirilmesine yönelik uygulamalar üzerinde durulmaktadır (Yenilmez ve Çimen, 2014). Çünkü öğretmenlerin veya öğretmen adaylarının matematikte problem kurma becerilerine sahip olmalarının birçok yararı vardır. Örneğin; ders kitaplarındaki problemler yetersiz olabilir, öğrencilerin seviyelerine uygun olmayabilir veya ilgi ve ihtiyaçlarına yanit veremeyebilir. Bu durumda, dersin amacına uygun işlenebilmesi için öğretmenin konu ile ilgili problemler kurması gerekebilir (Albayrak, 2000; Korkmaz ve Gür, 2006). Öğretmen adayları için de durum benzerdir. Gelecekte sınıf içi öğretim faaliyetlerinde problem kuracak ve öğrencilerinin kurduğu problemleri değerlendirecek olan (Işık vd., 2011) öğretmen adaylarının problem kurma becerilerinin geliştirilmesi bir zorunluluk olarak değerlendirilmelidir. Bu nedenle öğretim etkinliklerinde öğrencilerin ilgi ve ihtiyaçları göz önünde bulundurularak, düzeye uygun problem durumları oluşturulmasına (Yenilmez ve Çimen, 2014) yönelik uygulamalara öğretmen eğitiminde yer vermek ayrı bir öneme sahiptir. Öğretmen eğitimindeki tüm bu uygulamalara rağmen ülkemizde son yıllarda sayıları giderek artan bir şekilde Fen Fakültesi veya Fen-Edebiyat Fakültesi mezunlarına veya henüz mezun olmamış öğrencilerine pedagojik formasyon eğitimi verilerek öğretmenlik sertifikası kazandırılmaktadır. Pedagojik formasyon başvuru koşullarından biri YÖK tarafından şu şekilde belirlenmiştir: Üniversitelerin kurumsal kapasitesine bağlı olarak en erken lisans programlarının birinci sınıfını (ikinci yarı yılını) tamamlamiş öğrenciler, program açma izni verilen ilgili üniversitelerin eğitim/eğitim bilimleri fakültesi ve eğitim bilimleri bölümünde açılan pedagojik formasyon eğitimi sertifika programına başvurabilirler. Kontenjandan fazla öğrenci başvurusu olması durumunda daha üst sinıflarda olan öğrencilere öncelik verilir (YÖK, 2015). Görüldüğü gibi herhangi 4 yıllık ilgili fakültelerin birinci sınıfını tamamlamış öğrenciler bu sertifika programina başvurabilmektedir. Pedagojik formasyona başvuran öğrencilerin aldıkları zorunlu ve seçmeli dersler toplam 25 kredidir. Zorunlu ders olarak "Eğitim Bilimine Giriş", “Öğretim İlke ve Yöntemleri”, "Eğitimde Ölçme ve Değerlendirme", "Eğitim Psikolojisi", "Sınıf Yönetimi”, “Özel Öğretim Yöntemleri”, “Öğretim Teknolojileri ve Materyal Tasarımı", "Öğretmenlik Uygulaması" derslerini almaktadırlar (YÖK, 2015). Bu derslerin içerikleri incelendiğinde alan eğitimine yönelik olarak “Özel Öğretim Yöntemleri”, “Öğretim Teknolojileri ve Materyal Tasarımı”, “Öğretmenlik Uygulaması" derslerini sayabiliriz. 11 kredilik olan bu derslerin alanı öğretmeye yönelik öğrencilere yeterli beceriler kazandırıp kazand1ramadığı incelemeye değerdir. Dolayısıyla bu sertifikayı alarak öğretmenlik mesleğini yapma hakkını elde eden bireylerin aldıkları bu derslerle matematik öğretmenliği yapabilecek yeterliliği elde edip etmediklerine yönelik araştırmalara ihtiyaç duyulmaktadır. Öğretmen eğitimi kalitesinin arttırılması için pedagojik 
formasyon eğitimi alan öğretmen adayları ile ilgili çalışmaların arttırılması gerekir.

Pedagojik formasyon eğitimi alan öğrencilerin nasıl problemler kurdukları ve problem kurarken kullandıkları teknikler merak konusudur. Öğrencilerin kurdukları problemler analiz edilirken kullanılan farklı sinıflamalar bulunmaktadır. Bu sinıflamalar ise genellikle problem türlerine göre değişmektedir (Lave, Smith ve Butler; 1989; Akt. Akay, 2006; Lavy ve Bershadsky, 2003; Stonayova, 2003). Buna bağlı olarak mevcut çalışmada, pedagojik formasyon eğitimi alan matematik bölümü öğrencilerinin problem kurma becerilerinin incelenmesi amaçlanmıştır. Bu amaç doğrultusunda verilen farklı durumlara yönelik öğrencilerin kurdukları problemlerde kullandıkları teknikler irdelenmiştir.

\section{YÖNTEM}

Araştırma betimsel bir yaklaşımla özel durum çalışması yöntemi ile yürütülmüştür. Özel durum çalışmalarında bir ya da birden fazla olay, ortam, program, sosyal grup ya da birbirine bağlı sistemler derinlemesine incelenmektedir (Büyüköztürk, Kılıç Çakmak, Akgün, Karadeniz ve Demirel, 2009). Bu çalışmada da bir öğrenci grubu problem kurma becerisi yönünden derinlemesine incelendiğinden dolayı özel durum çalışmasıdır.

\section{1 Çalışma Grubu}

Çalışma grubunu Türkiye'nin kuzey doğusunda bir devlet üniversitesinin eğitim fakültesinde pedagojik formasyon eğitimi alan 46 matematik bölümü öğrencisi oluşturmaktadır. Çalışmanın yapıldığı dönemde matematik öğretmenliği pedagojik formasyon eğitiminde toplam 4 şube bulunmaktadır. Yapılan çalışmada şube basit tesadüfi örnekleme yöntemi ile seçilmiş ve o şubede yer alan öğrencilerle çalışma gerçekleştirilmiştir. Katılımcılar hafta içi Fen Fakültesindeki derslerine devam ederken hafta sonu her iki günde pedagojik formasyon eğitimine devam etmektedirler. Katılımcıların $24^{\prime}$ ü (\%52) bayan ve 22 'si (\%48) de erkektir. Çalışmaya katılan öğrencileri temsil etmesi için Ö1, Ö2, Ö3,..., Ö45, Ö46 şeklinde kodlar kullanılmiştır.

\subsection{Veri Toplama Aracı}

Veriler, kişisel bilgi formunun yanı sıra Korkmaz ve Gür (2006) tarafından geliştirilen “Matematik Öğretimi ve Problem Kurma" testi ile elde edilmiştir. Kişisel bilgi formunda katılımcıları tanımaya yönelik 7 tane soru yer almaktadır. Bu sorular, katılımcıların cinsiyet, yaş ve not ortalamaları gibi demografik bilgiler içeren sorulardır. "Matematik Öğretimi ve Problem Kurma" testi ise öğrencilerin problem kurma becerilerini belirlemeye yönelik 4 farklı durum içeren etkinliklerden oluşmaktadır. Bunlardan;

1. durum; verilen açık uçlu problem ifadesini değiştirerek, onun bir tür uyarlaması (modifikasyonu) olan bir problemin ortaya atılmasıdır. Bu durum öğrencilere,

“Aşağıdaki problemi değiştirerek yeni bir problem kurunuz.

"Aşağıda iki iş önerisi vardır. Hangi işin daha kazançlı olduğunu belirleyiniz. Öneri 1: A şirketinde, bir saatte 7,40TL kazanacaksiniz. Bununla birlikte, çalışmak için kendinize 67TL ya bir üniforma almaniz gerekiyor. Haftada toplam 20 saat çalışacaksınız.

Öneri 2: B şirketinde, bir saatte 5,80 TL kazanacaksinız. Çalışmak için özel bir üniforma almanıza gerek yoktur. Haftada toplam 20 saat çalışacakstniz."

şeklinde verilmiştir.

2. durum; verilen sayı ve işlemleri kullanarak problemler kurmaya yöneliktir. Bu durum öğrencilere aşağıdaki biçimde sunulmuştur. 
“320, 60 ve 41 sayllart ile çarpma, bölme ve çıkarma işlemleri kullanılarak çözülebilecek bir problem kurunuz."

3.durum; öğrencilerden verilen matematiksel eşitlikleri kullanarak çözülebilen problemler kurmaları istenilmiştir ve öğrencilere;

"90×6=540 540+85=625 eşitliklerini kullanarak çözülebilen bir problem kurunuz."

olarak sunulmuştur.

4. durumda da esas bileşeninin eksik olduğu, matematiksel olarak veri ve bilgi içeren durumlar verilmiş ve bunları kullanarak problem ortaya atılması beklenmiştir. Durum öğrencilere aşağıdaki biçimde verilmiştir.

"Aşağıldaki olaya dayanan bir problem kurunuz.

"64 dairelik bir siteye yüzme havuzu yapılması planlaniyor. Yapilacak havuzun $6 \mathrm{~m}$ eninde, $21 \mathrm{~m}$ boyunda ve $4 \mathrm{~m}$ yüksekliğinde olması kararlaştırlliyor. Site sakinleri için havuza giriş ücretleri (bir saat için), 9:00 - 13:00 arası 2,50 TL, 13:00 19:00 arası 3,50 TL, Site sakini olmayanlar için ise ücret, 4,50 TL dir."

Testin geçerlik ve güvenilirliği Korkmaz ve Gür (2006) tarafından sağlanmış olup Cronbach alpha güvenirlik katsayısı $0,78^{\prime}$ dir.

\subsection{Verilerin Toplanması}

Verilerin toplanması sürecinde kişisel bilgi formu ve "Matematik Öğretimi ve Problem Kurma" testinde yer alan etkinlikler katılımcılara yazılı olarak verilmiştir. Uygulamalar ikinci dönemin sonunda gerçekleştirilmiştir. Bu süreçte her bir durumun altında katılımcıların çalışması için yeter miktarda boş alan bırakılmıştır. Uygulama sürecinde katılımcılar sınav düzeninde yerleştirilerek birbirlerinden etkilenmeleri engellenmeye çalışılmıştır. Katılımcıların testteki etkinlikleri yapmaları yaklaşık olarak 35-40 dakikalarını almıştır.

\subsection{Verilerin Analizi}

Veriler, içerik analizine tabi tutulmuş ve araştırmanın amacı kapsamında öğrencilerin problem kurma becerilerini ortaya koymak için "problem", "problem değil" ve "boş" şeklinde temalar oluşturulmuştur (Iş̧ı, Iş̧ı ve Kar, 2011). Bu temalardan bir çözümü bulunanlar "problem" olarak nitelendirilmiş ve kurulan problemlerin ortaöğretim düzeyindeki kazanımları içerip içermemesi dikkate alınmamıştır. Bunun yanı sıra yanlış veya eksik veri ile kurulduğu için

çözümü olmayan durumlarda "problem değil" olarak isimlendirilmiştir. Herhangi bir problem durumu yazılmayıp tamamen boş bırakıldığında ve verilen durum birebir aynı biçimde yazıldığında da "boş" olarak nitelendirilmiştir. Temaların altında da öğrencilerin yazdıklarından problem niteliği taşıyanlar tekrar analiz edilerek kodlanmıştır. Bu kodlamalar ise öğrencilerin kurdukları problemlerde kullandıkları teknikleri belirlemek amaciyla yapılmıştır. Iş̧ı, Iş̧ı ve Kar (2011) bu sınıflama sonucunda "problem" olarak değerlendirilen yanitları "ödev", "ilişkisel" ve "koşullu" olarak sınıflandırmışlardır. Ancak bu çalışmada kodlar problem kurmak için verilen verilere ve durumlara göre diğer bir ifadeyle etkinliklere göre farklılık göstermektedir. İlk durum için oluşturulan kodlarda Tertemiz ve Sulak (2013)'ın kullandıkları sinıflamadan yararlanılmıştır. Tertemiz ve Sulak (2013) araştırmalarının sonucunda Lave, Smith ve Butler (1989)'in, (Akt. Akay, 2006) siniflandırmasına bir madde (8. madde) daha eklemişlerdir. Bu sınıflama aşağıdaki gibidir:

1. Verilen ve istenen bilgiyi ters çevirme

2. Yeni bilgi ekleme

3. Koşulları ve konuyu değiştirmeyip, verilen verilerin değerlerini değiştirme 
4. Verilen verileri ve koşulları değiştirmeyip, konuyu değiştirme

5. Verilen verileri ve konuyu değiştirmeyip, koşulları değiştirme

6. Bağlamı veya problemin kuruluşunu değiştirme

7. Verilen bir ifadenin bir veya daha fazla parçasının çelişmesi

8. Verilen verileri ve konuyu değiştirip, koşulları değiştirmeme

Bu çalışmada Tertemiz ve Sulak (2013)'ın kullandıkları sinıflamada yer alan kodların tamamı ortaya çıkmamış ancak ortaya çıkan yeni kodlar eklenmiştir. Birinci durum için oluşturulan kodlar; yeni bilgi ekleme, koşulları ve konuyu değiştirmeyip verilen verilerin değerini değiştirme, verilen verileri ve koşulları değiştirmeyip konuyu değiştirme, verilen verileri ve konuyu değiştirmeyip koşulları değiştirme, bağlamı veya problemin kuruluşunu değiştirme, verilen verileri ve konuyu değiştirip, koşulları değiştirmeme, verilen verileri, konuyu ve koşulları değiştirme biçimindedir. İkinci durumun kodları; işlemlerin ve sayısal verinin tamamının kullanılması, işlemlerin tamamının kullanılmaması, sayısal verinin tamamının kullanılmaması, işlemlerin ve sayısal verinin tamamının kullanılmaması, işlemlerin tamamının kullanıp sayısal verinin tamaminın kullanılmaması ve yeni sayısal veri eklenmesi ile yeni veri eklenmesidir. Üçüncü durumda verilen verinin tamamını kullanma ve verilen verilere yeni veri ekleme kodları bulunmaktadır. Dördüncü durumda ise veri tam, eksik veri ve konu farkll, veri tam ama konu farkll, konu ve veri farkll, veri tam ama ek sayısal veri bulunmakta, veri eksik kullanılmış ama yeni sayısal veri eklenmiş, eksik veri biçiminde kodlar yer almaktadır.
Problem kurma becerilerinin sinıflandırılmasında ve kullanılan tekniklerin analizinde kodlamalar yapılırken araştırmacıların dışında 2 matematik eğitimi uzmanının da görüşleri alınmıştır. Uzman görüşlerine, öğrencilerin yazdıklarının problem ve problem değil şeklinde sınıflandırılmasında başvurulmuştur. Bu süreçte kodlama güvenirliğinin sağlanması amacıyla 46 katılımcının verdikleri yanıtlar her iki araştırmacı tarafından ayrı ayrı sınıflandırılarak kodlanmıştır. İki araştırmacının kodları karşılaştırılarak görüş birlikleri ve ayrılıkları belirlenmiştir. Buradan hareketle güvenirlik katsayısı, Miles ve Huberman'ın (1994); (Güvenirlik Katsayısı=Görüş Birliği Sayıs1/(Görüş Birliği Sayısı+Görüş Ayrıllğ1 Sayısı) formülü kullanılarak 0,91 gibi yüksek bir değer bulunmuştur. Sınıflandırmalar arasındaki tutarlılığa bakılmış, farklı olarak yapılan sınıflandırmalar üzerinde tartışılarak görüş birliğine varılmıştır.

\section{BULGULAR}

Araştırmadan elde edilen bulguların sunumunda öncelikli olarak öğrencilerin problem kurma becerilerine ilişkin durum genel olarak verilmiştir. Daha sonra problem niteliği taşıyan öğrenci yanıtları her problem durumu için ayrı ayrı sunulmuştur. Bunun ardından da problem niteliği taşımayan öğrenci yanıtlarına yer verilmiştir.

Verilerin analizi sonucunda öğrencilerin, farklı içeriklerdeki 4 farklı problem durumundan bazılarında daha kolay problem kurabilirken diğer bazılarında problem kurmakta daha çok zorlandıkları tespit edilmiştir. Öğrencilerin verilen durumlara göre problem kurupkuramama durumları Tablo 1'de belirtilmiştir. 
Tablo 1. Öğrencilerin problem kurma durumları

\begin{tabular}{lcccc}
\hline & Problem $(\mathrm{N})$ & Problem değil $(\mathrm{N})$ & Boş(N) & Toplam (N) \\
\hline 1. Durum & 23 & 9 & 14 & 46 \\
2. Durum & 36 & 7 & 3 & 46 \\
3. Durum & 44 & 1 & 1 & 46 \\
4. Durum & 21 & 16 & 9 & 46 \\
Toplam & 124 & 33 & 27 & 184 \\
\hline
\end{tabular}

Tablo 1'e bakıldığında öğrencilerin toplam 184 durumdan 124 tanesinde problem kurdukları görülmektedir. Bunun yanı sıra öğrencilerin verilen durumlara yönelik yazdıklarının 33'ü problem değildir. Ayrıca öğrencilerin 27'si de verilen durumlara herhangi bir şey yazamayarak boş bırakmışlardır. "Matematik Öğretimi ve Problem Kurma" testinde yer alan birinci durum için problem kurabilen 23 öğrenci, yazdıkları problem niteliği taşımayan 9 öğrenci ve boş bırakan da 14 öğrenci bulunmaktadır. İkinci duruma yönelik olarak problem kurabilen 36 öğrenci, yazdıkları problem değeri taşımayan 7 öğrenci ve boş bırakan 3 öğrenci mevcuttur. Üçüncü durumda problem kurabilen 44 öğrenci varken 1 öğrencinin kurduğu problem değildir ve 1 öğrenci de boş bırakmıştır. Dördüncü durum için 21 öğrenci problem kurabilmiş, 16 öğrenci problem ku- ramamış ve 9 öğrenci de boş bırakmıştır. $\mathrm{Bu}$ süreçte öğrencilerin en çok problem kurabildikleri 3. durum iken en çok yanlış problemi de 4. durumda kurmuşlardır. Bunun yanı sıra problem kuramayarak en çok boş bıraktıkları durumda 1. durum olmuştur.

\subsection{Problem Niteliği Taşıyan Öğrenci Yanitlarına Ait Bulgular}

Testte yer alan her durum için yapılan analiz sonuçları aşağıda ayrı ayrı sunulmuştur.

\subsubsection{Durum 1}

Öğrencilere verilen birinci durumda bir problem vardır ve öğrencilerden bu problemi değiştirerek yeni bir problem kurmaları istenmektedir. Tablo 2'de toplam 23 öğrencinin 1. durumda kurdukları problemlerde kullandıkları tekniklerin frekansı yer almaktadır.

Tablo 2. Öğrencilerin 1. durumda kullandıkları problem kurma teknikleri

\begin{tabular}{ll}
\hline Problem kurma teknikleri & $\mathrm{f}$ \\
\hline Verilen verileri ve koşulları değiştirmeyip, konuyu değiştirme & 8 \\
Verilen verileri ve konuyu değiştirmeyip, koşulları değiştirme & 6 \\
Koşulları ve konuyu değiştirmeyip, verilen verilerin değerini değiştirme & 3 \\
Yeni bilgi ekleme & 2 \\
Verilen verileri, konuyu ve koşulları değiştirme & 2 \\
Bağlamı veya problemin kuruluşunu değiştirme & 1 \\
Verilen verileri ve konuyu değiştirip, koşulları değiştirmeme & 1 \\
Toplam & 23 \\
\hline
\end{tabular}


Tablo 2'ye bakıldığında öğrencilerin problem kurarken en çok kullandıkları tekniğin verilen

verileri ve koşulları değiştirmeyip, konuyu değiştirme olduğu görülmektedir. Daha sonra ise en çok kullanılan teknik verilen verileri ve konuyu değiştirmeyip, koşulları değiştirmedir. Bunun yanı sıra öğrencilerin en az kullandıkları teknik ise bağlamı veya problemin kuruluşunu değiştirme ile verilen verileri ve konuyu değiştirip, koşulları değiştirmeme olmuştur.
Çalışmaya katılan öğrencilerden 8'i (Ö6, Ö10, Ö27, Ö30, Ö38, Ö40, Ö41, Ö42) verilen verileri ve koşulları değiştirmeyip konuyu değiştirmişlerdir. Bu süreçte hastanede yapılan ihaleye iki firmanın girmesi veya işçilerin inşaatta çalışması gibi konulara yer vermişlerdir. Bu konulardan farklı olarak Ö6 ise seyahat konusunu kullanarak (bkz. Şekil 1) problem kurmuştur. Öğrenci problemi kurarken bir şoförün seyahate çıkmadan önce aracına bakım yaptırması şeklinde bir konuya yer verilmiştir.

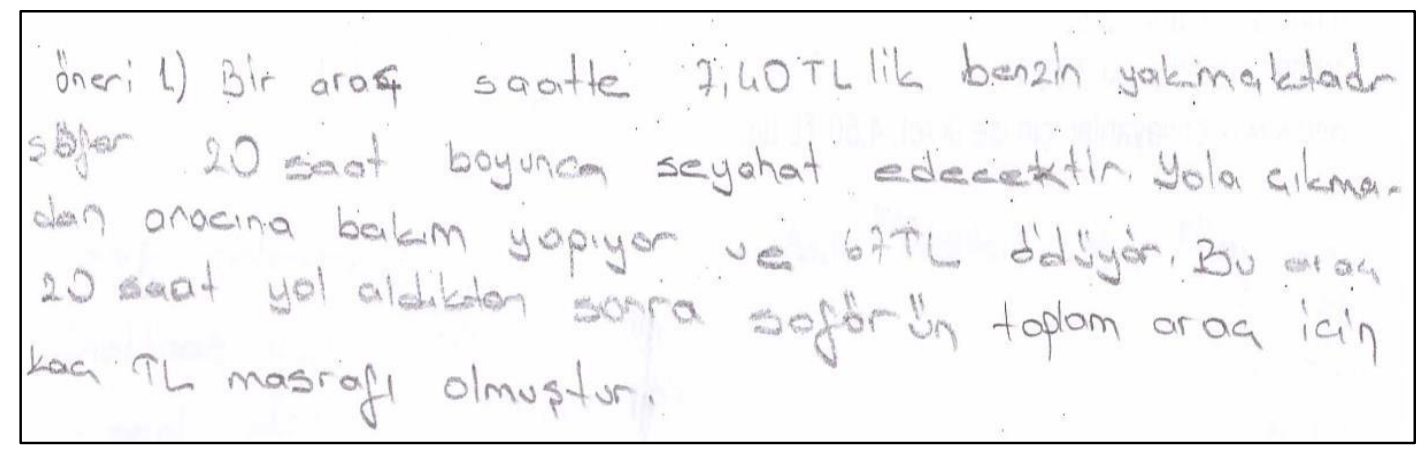

Şekil 1. Ö6'nın durum 1'e yazdığı problem örneği

Öğrencilerden 6's1 (Ö3, Ö4, Ö18, Ö29, Ö36, Ö46) verilen verileri ve konuyu değiştirmeyip koşulları değiştirmiştir. Örneğin koşulları değiştiren öğrencilerden biri (Ö18) üniformanın 6 ayda bir değiştirilmesi gerektiğini belirtmiştir.

Öğrencilerden 3'ü (Ö7, Ö21, Ö43) problemde verilen koşulları ve şirketin kazanç durumuna yönelik olan konuyu değiştirmemişler fakat verilen verilerin değerlerini değiştirmişlerdir. Koşulları ve konuyu değiştirmeyerek verilen verilerin değerini değiştiren öğrencilerden birisi Ö43 durum 1'de verilen 7,40TL ve 5,80TL yerine $148 \mathrm{TL}$ ve $116 \mathrm{TL}$ gibi farklı sayısal veriler kullanmıştır.

Birinci durumda problem kurabilen 23 öğrenciden 2'si (Ö1, Ö17) problemde verilenlere yeni bilgi eklemiştir. Bunu yapan öğrenciler problemde verilen sayısal verilerin dışında ek bir sayısal veri daha ekleyerek yeni bir problem kurmuşlardır. Katılımcılardan 2'si (Ö11, Ö28) de verilen verileri, konuyu ve koşulları değiştirmiştir. Bu öğrencilerden Ö28 kodlu öğrenci;

“100km yol aldığımızda hangi araçla daha kazançlı oluruz?

Öneri 1. Aracı kilometrede 40 kuruş yakıt harcıyor. Her $100 \mathrm{~km}$ yol aldığında 50TL'lik bakıma ihtiyaç duyuyor.

Öneri 2. TS aracı kilometrede 33 kuruş yakıt harcıyor. Her $100 \mathrm{~km}$ yol aldiğında 27TL'lik bakıma ihtiyaç duyuyor."

şeklinde bir problem kurarak problemin verilerini, konusunu ve koşullarını değiştirmiştir. Katılımcı öğrencilerin 1'i bağlamı veya problemin kuruluşunu değiştirmiştir. Ö8 kodlu bu öğrencinin problemi “Günde 20 saat çalışıp saatte 
7.40TL kazanan bir kişi 67 saat çalışır ve devamında saatte 5.80TL kazançla 1 gün daha çalısıırsa kaç lira kazanır?" biçimindedir. Bu problemde izlenen işlem basamakları verilen problemin işlem basamaklarından farklıdır ama çözülebilen bir problemdir. Ayrıca öğrencilerden bir diğeri de
(Ö44) verilen verileri ve konuyu değiştirip koşulları değiştirmemiştir.

\subsubsection{Durum 2}

Araştırmaya katılan öğrencilerin durum 2'de kullandıkları problem kurma teknikleri Tablo 3'de yer almaktadır.

Tablo 3. Öğrencilerin 2. durumda kullandıkları problem kurma teknikleri

\begin{tabular}{lc}
\hline Problem kurma teknikleri & $\mathrm{f}$ \\
\hline İşlemlerin tamamının kullanılmaması & 14 \\
İşlemlerin ve sayısal verinin tamamının kullanılması & 12 \\
Yeni veri eklenmesi & 4 \\
İlemlerin tamamının kullanıp sayısal verinin tamamının kullanılmaması & 3 \\
ve yeni sayısal veri eklenmesi & \\
Sayısal verinin tamamının kullanılmaması & 2 \\
İşlemlerin ve sayısal verinin tamamının kullanılmaması & 1 \\
Toplam & 36 \\
\hline
\end{tabular}

Tablo 3'de 2. durumda kullanılan problem kurma teknikleri bulunmaktadır. Katılımclardan 14'ü kurdukları problemlerde işlemlerin tamamını kullanmamıştır. İşlemlerin tamamını kullanmayan öğrencilerden 3'ü (Ö28, Ö37, Ö38) çarpma, 5'i (Ö39, Ö40, Ö42, Ö41, Ö44) çıarma, 2'si (Ö43, Ö45) bölme, 3'ü (Ö10, Ö11, Ö46) çarpma ve bölme, 1'i (Ö2) de bölme ve çlkarma işlemini kullanmamıştır. Aşağıda yer alan Şekil 2'de Ö40 kodlu öğrencinin çıkarma işlemi kullanmadan kurduğu örnek bulunmaktadır.

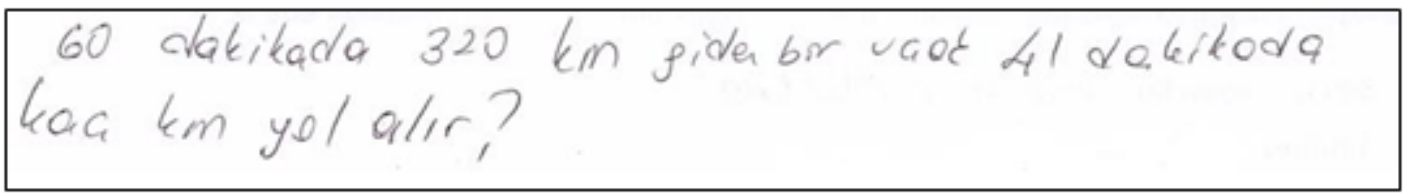

Şekil 2. Ö40'ın durum 2'ye yazdığı problem örneği

İkinci durumda problem kurabilen toplam 36 bir problem kurmuşlardır. Bu öğrencilerden öğrenciden 12'si (Ö6, Ö7, Ö8, Ö14, Ö15, Ö17, Ö18, Ö19, Ö23, Ö24, Ö25, Ö34) verilen sayıların Ö7'nin kurduğu problem örneği Şekil 3'de yer almaktadir. ve işlemlerin tamamını kullanarak çözülebilir

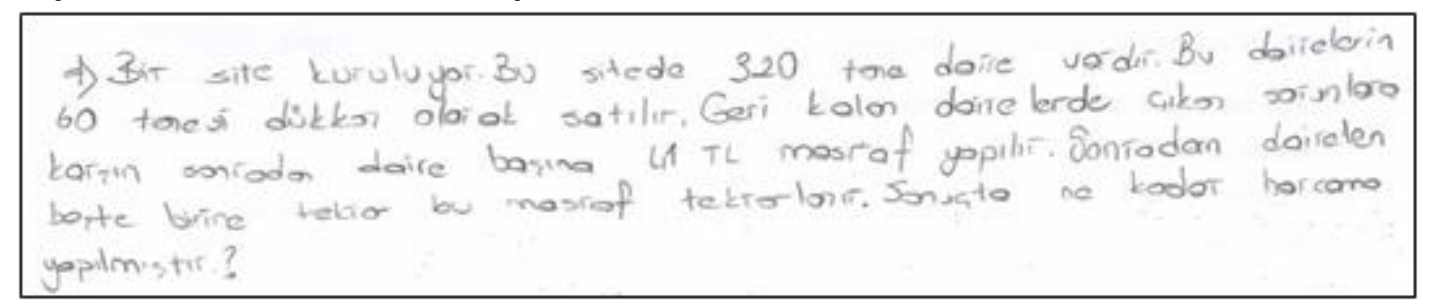

Şekil 3. Ö7'nin durum 2'ye yazdığı problem örneği

İşlemlerin hepsini kullanmayan öğrencilerin yanı sıra 2 öğrenci de sayısal verinin hepsini kullanmamıştır. $\mathrm{Bu}$ katılımcıların her ikisi (Ö1, Ö22) de sayısal veri olan " 41 " $\mathrm{i}$ 
kullanmamışlardır. Problem kurabilen öğrencilerden 1'i (Ö33) hem işlem ve hem de sayısal verilerin hepsini kullanmamıştır. Bu öğrenci sayısal veriden “320" yi ve işlemlerden de bölme ve çıkarmayı kullanmamıştır. Katılan öğrencilerden 4’ü (Ö5, Ö9, Ö12, Ö13) ise problem kurmak için yeni veri eklemişlerdir. Bu öğrencilerin dördü de verilen verilere ek olarak "10", “23" gibi yeni bir sayısal veri eklemişlerdir. Bu katılımcılardan Ö23'de problemi doğru kurarak verilen bütün veriyi kullanmış ve ek olarak 23 sayısını da probleme eklemiştir. Problem kuran öğrencilerden 3'ü (Ö3, Ö4, Ö21) ise verilen sayısal verileri kullanmayıp işlemlerin tamamını kullanmış ve ayrıca bir de yeni sayısal veri eklemişlerdir.

\subsubsection{Durum 3}

Üçüncü durumda öğrencilerin kurdukları problemlerin teknikleri aşağıda (bkz. Tablo 4.) yer almaktadir.

Tablo 4. Öğrencilerin 3. durumda kullandıkları problem kurma teknikleri

\begin{tabular}{lc}
\hline Problem kurma teknikleri & $\mathrm{f}$ \\
\hline Verinin tamaminin kullanılmasi & 35 \\
Yeni veri eklenmesi & 9 \\
Toplam & 44 \\
\hline
\end{tabular}

Tablo 4'de öğrencilerin 3. durum için kullandıkları problem kurma teknikleri ve frekansları yer almaktadır. Üçüncü durum için problem kurabilen 44 öğrenciden 35'i verinin tamamını kullanmış ve 9'u da yeni veri ekley- erek problem kurmuşlardır. Şekil 4'de 3. durumda verilmiş olan bütün veriyi problem kurmada kullanan Ö2 kodlu öğrencinin yazdığ1 problem görülmektedir.

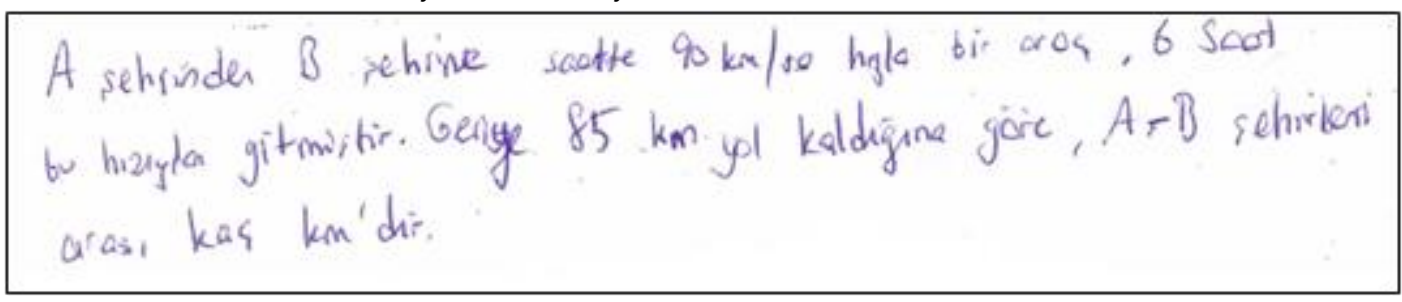

Şekil 4. Ö2'nin durum 3'e yazdığ́ problem örneği

Yeni veri ekleyerek problem kuran katılımclardan 5’i (Ö3, Ö5, Ö22, Ö34, Ö35) farklı bir işlem ve farklı bir sayısal veri kullanmıştır. Örneğin Ö22 kodlu öğrencinin kurduğu problem; "Her gün 90 yumurta veren tavuklar 6 günde kaç yumurta yapar. Bu yumurtalara hafta içi 17 yumurta daha eklenirse toplam kaç yumurta olur? (Not: 1. gün pazartesi)" biçimindedir. Öğrenci kurduğu problemde verilen durumun dışında farklı bir işlem ve farklı bir sayısal veri kullanmıştır. Burada kurulan problemi çözmek için 3. durumda yer almayan 17 sayısı ile 5 sayısının çarpımının yapılması gerekmektedir. Yeni veri ekleyen öğrencilerden 2'si (Ö13, Ö38) ek sayısal veri kullanırken, 2'si (Ö32, Ö33) de ek bir işlem kullanmıştır. Üçüncü durumda Ö31 kodlu öğrenci boş bırakırken Ö1 kodlu öğrenci de problem niteliği taşımayan bir ifade yazmıştır.

\subsubsection{Durum 4}

Araştırmaya katılan öğrencilerin durum 4'de kullandıkları problem kurma teknikleri Tablo 5'de yer almaktadir. 
Tablo 5. Öğrencilerin 4. durumda kullandıkları problem kurma teknikleri

\begin{tabular}{ll}
\hline Problem kurma teknikleri & $\mathrm{f}$ \\
\hline Verinin tamamını kullanma ve ek sayısal veri kullanma & 7 \\
Verinin tamamını kullanma & 5 \\
Eksik veri ve konuyu farklı kullanma & 3 \\
Veriyi tam ama konuyu farklı kullanma & 3 \\
Konuyu ve veriyi farklı kullanma & 1 \\
Veriyi eksik kullanma ve yeni sayısal veri ekleme & 1 \\
Eksik veri kullanma & 1 \\
Toplam & 21 \\
\hline
\end{tabular}

Tablo 5'e bakıldığında öğrencilerin dördüncü durum için en çok kullandıkları problem kurma tekniğinin verinin tamamını kullanma ve ek sayısal veri kullanma şeklinde olduğu görülmektedir. Ayrıca en az kullandıkları teknikler de konuyu ve veriyi farklı kullanma, veriyi eksik kullanma ve yeni sayisal veri ekleme ve son olarak da eksik veri kullanma biçimindedir.
Dördüncü durum için problem kuran öğrencilerden 7'si (Ö7, Ö12, Ö14, Ö15, Ö16, Ö42, Ö45) verilen veriyi tam olarak kullanmış ve bunlara yeni sayısal veri eklemişlerdir. Bu öğrencilerden Ö16 verilen veriye ek olarak havuzda atılan tur sayısını ve indirimler olmak üzere yeni sayısal veri ilave etmiştir. Şekil 5'de Ö16'nın durum 4 için yazdığı problem görülmektedir.

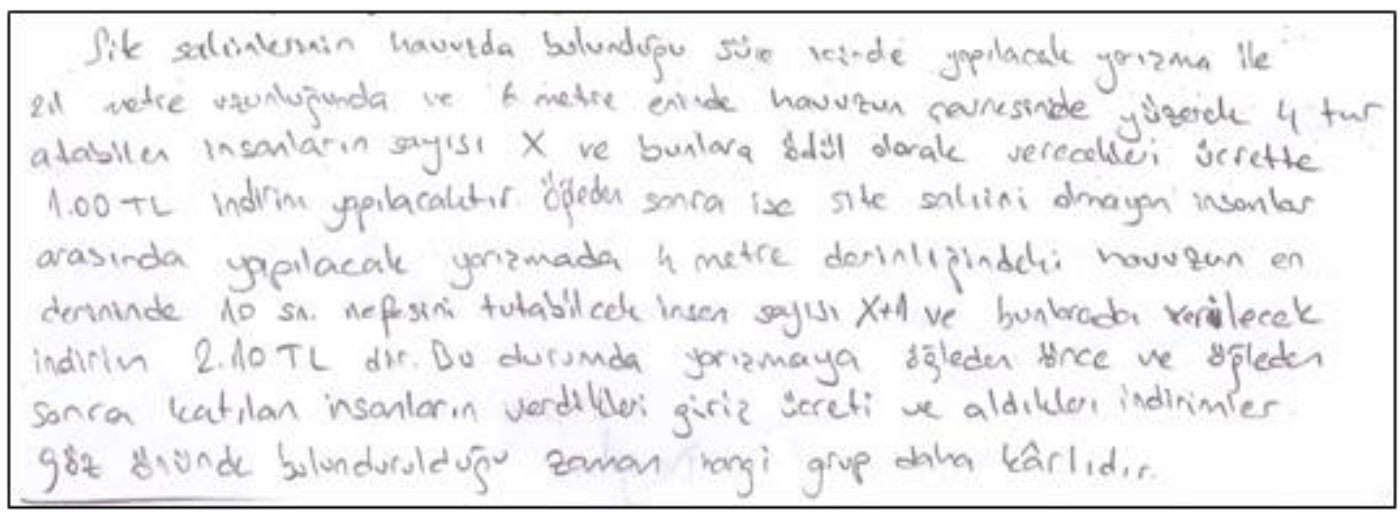

Şekil 5. Ö16'nın durum 4'e yazdığı problem örneği

Dördüncü durumda problem kuran 21 öğrenciden 5'i (Ö4, Ö11, Ö13, Ö26, Ö40) verilen verinin hepsini kullanmıştır. Çalışmaya katılan öğrencilerden 3'ü (Ö18, Ö36, Ö41) veriyi eksik ve konuyu farklı alarak problem kurmuşlardır. $\mathrm{Bu} \quad 3$ öğrencide sayısal verilerden birini kullanmamıştır. Ayrıca bu öğrencilerden birisi (Ö18) Durum 4'de verilen site havuzu yerine sınıf, bir öğrencide (Ö41) kafe tanımlayarak konuyu değiştirmiştir. Diğer bir öğrenci (Ö36) de havuzun yanı sira kitap ve hamburger alma gibi durumlar ile konuyu farklılaştırmıştır.

Çalışmaya katılan öğrencilerden 3'ü (Ö6, Ö17, Ö38) problem kurarken verilen verilerin tamamını kullanmış fakat havuz yerine farklı 
konuda problemler kurmuşlardır. Bunlardan bir öğrenci (Ö38) kumbara, bir öğrenci (Ö6) futbol sahası ve bir öğrenci (Ö17) de otopark kullanarak problem kurmuştur. Durum 4 için problem kuran öğrencilerden 1'i (Ö22) farklı konu ve farklı veri kullanmıştır. Bu öğrenci (Ö22) konu olarak havuz yerine otopark kullanırken verilen sayısal verileri de tamamen değiştirmiştir. Çalışmada yer alan öğrencilerden 1'i (Ö44) verilen veriyi eksik kullanmış ama problem kurmak için yeni bir sayısal veri eklemiştir. Öğrencilerden 1'i (Ö21) de problemde yer alan verinin tamamını kullanmayarak eksik veri ile problem kurmuştur.

\subsection{Problem niteliği taşımayan öğrenci yanıt- larına ait bulgular}

Uygulanan testte katılımcıların doğru biçimde kurdukları problemlerin yanı sira problem niteliği taşımadığı için problem kabul edilmeyen yanıtları da bulunmaktadır. Problem olmayan yanıtlarda ise öğrenciler bazen eksik veri içeren durumlar yazmış ve bazen de verinin tamamını kullanmalarına karşın çözülmesi olası olmayan durumlar yazmışlardır. Bunun yanı sıra bazı katılımcılar da verilen duruma yönelik yazdığı ifadede verileri vermiş fakat problem cümlesine yer vermemiştir. Öğrencilerden Ö26'nın testte yer alan durum 1 için yazdı $\breve{1}$ ifade problem olarak nitelenemeyecek olan ifadelerden biridir (bkz. Şekil 6). Öğrenci yazmış olduğu ifade de öncelikli olarak verilen durum 1 için kazançlı olan öneriyi belirterek problem durumunun yanıtını vermiştir. Bunun ardından ise yazdığ 1 ifade de alınması gereken malzemelerin fiyatlarını ve haftada ne kadar çalışılacağını belirtmiş ancak problem cümlesini yazmamıştır. Bu nedenle yazılan ifadede ne sorulduğu diğer bir ifadeyle istenen belli değildir.

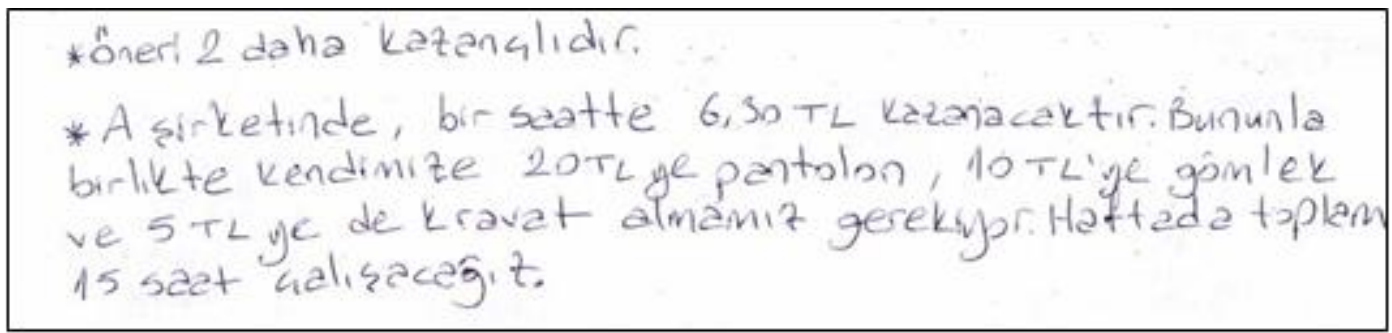

Şekil 6. Problem olmayan öğrenci yanıtı (Ö26 Örneği)

Öğrencilerden Ö1 verilen durum 4 için yazdığ 1 ifade de havuz yerine kulübeler tanımlamıştır (bkz. Şekil 7). Katılımcı yazdı̆̆ı ifade de verilen durumda yer alan verilerin tamamını kullanmıştır. Fakat yazdığı ifade de tatil beldesinde kaç tane kulübe olduğunu belirtmediği için problemin çözülmesi olası değildir.

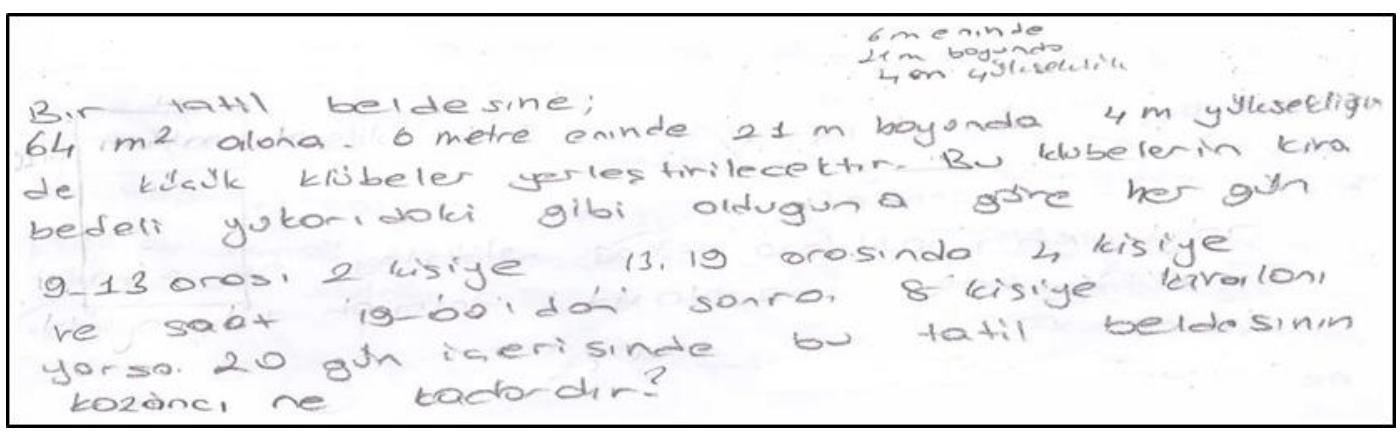

Şekil 7. Problem olmayan öğrenci yanıtı (Ö1 Örneği) 
Problem kuramayan öğrencilerden birisi (Ö31) verilen dört durumdan üçünü boş bırakmış ve ikinci durum için de çözülemeyecek yanlış bir problem kurmuştur.

\section{TARTIŞMA VE SONUÇ}

Araştırma kapsamında pedagojik formasyon eğitimi alan matematik bölümü öğrencilerinin verilen durumlara yönelik kurdukları problemler incelenmiştir. Sonuç olarak, öğrencilerin yarısından fazlasının kendilerine verilen durumlara ilişkin problem kurabildikleri ortaya çıkmıştır. Ancak bununla birlikte öğrencilerin yaklaşık yarısının testte yer alan durumlara yönelik yazdıklarının problem niteliği taşımadığı veya boş bıraktıkları görülmüştür. Problem niteliği taşımayan ifadeler, en fazla dördüncü durum için söz konusu iken boş bırakma daha çok birinci durumda tespit edilmiştir. Öğrencilerin kurdukları problemlerin ise daha çok sayı ve işlemler içeren durumlara yönelik olduğu belirlenmiştir. $\mathrm{Bu}$ sonuç alan yazındaki benzer çalışmaların sonuçları ile örtüşmektedir. Korkmaz ve Gür (2006) yaptıkları çalışmada sınıf ve matematik öğretmeni adaylarının, problem kurarken ağırlıklı olarak sözel dört işlem problemlerini kullandıklarını tespit etmişlerdir. Bunar (2011) ise altıncı sınıf öğrencileri ile yaptı̆̆ çalışmada, matematik dersinde problem kurma ve çözme becerilerini incelemiş ve öğrencilerin büyük bir çoğunluğunun problem kurmada başarılı olduklarını belirlemiştir. Ancak öğrencilerin en başarılı oldukları problem kurma türü ise "verilen bilgileri (şekil, cümle, sayı, vb.) kullanarak problem kurma" olarak ortaya çıkmıştır. Farklı gruplar üzerinde yapılmış araştırmalarda benzer sonuçlara ulaşılmış olması öğrencilerin öğrenim yaşantılarının problem kurma becerileri üzerindeki etkilerinin yansımaları olarak görülebilir. Öğrencilerin öğrenim yaşantılarında kullandıkları ders kitaplarının, ek kaynakların ve matematik öğretmenlerinin sınıf içi uygulamalarının genellikle sayılar ve işlemler ağırlıklı olduğundan dolayı kurdukları problemlerde bu yaşantılarını yansıttı̆̆ 1 söylenebilir.

Araştırmaya katılan öğrencilerin problem kurmada en başarılı oldukları durum 3, verilen matematiksel eşitlikleri kullanarak çözülebilen problem kurmaların gerektiriyordu. $\mathrm{Bu} \mathrm{du}-$ rumda öğrencilerin ikisi hariç diğer tümü çözülebilir problemler kurmuşlardır. Ancak farklı işlem ve farklı sayısal veri, farklı sayısal veri ya da farklı işlem ekleyerek problem kuran öğrenciler de olmuştur. Durum 2'de ise öğrenciler verilen sayı ve işlemleri kullanarak problem kurmayı denemiş ve büyük bir kısmı başarılı olmuştur. Ancak problemlerine yeni işlem/yeni veri ekleyen veya işlemlerin/sayısal verilerin tamamını kullanmayan öğrenciler de olmuştur. Öğrencilerin durum 2 ve durum 3 için kurdukları problemler incelendiğinde problem çeşitlerinin sınırlı olduğu ve basit hesaplamalar ile çözülebilecek problemlerin daha fazla olduğu belirlenmiştir. Bu sonuç, matematik öğrencilerinin kurdukları problemlerin çoğunlukla tahmin edilebilir, basit veya iyi yapılandırılmamış olduğu şeklinde yorumlanabilir. Işık, Işık ve Kar (2011) yaptıkları çalışmada, matematik öğretmeni adaylarının sözel ve görsel temsillere yönelik kurdukları problemleri analiz etmişler ve öğretmen adaylarının farklı temsillere yönelik problem kurma başarılarının genel olarak düşük olduğunu belirlemişlerdir. Benzer biçimde Kırnap-Dönmez (2014) de yapmış olduğu çalışmasında ilköğretim matematik öğretmen adaylarının problem kurma becerilerini incelemiş ve öğretmen adaylarının birçoğunun problem kurma ile ilgili eksikliklerinin olduğunu saptamıştır. Çalışmasına katılan öğretmen adaylarının yarısından azı verilen durumlara uygun olacak şekilde problem kurabilmişlerdir. Benzer sonuçlara ulaşmış araştırmaların sonuçları şu şekilde yorumlana- 
bilir. Öğrencilerin öğrenim yaşantıları dikkate alındığında derslerde öğretmenlerin problem kurma etkinliklerinden ziyade problem çözme etkinliklerine daha çok yer verdikleri ve hatta problemlerin çoktan seçmeli testler şeklinde doğru cevabı bulmaya odaklı çözüldüğü bilinmektedir. Bu tür sınıf içi uygulamalar öğrencilerin ortaöğretim sonrasındaki öğrenim süreçlerinde de devam etmektedir. Dolayısıyla öğrencilerde problem kurmaya ilişkin deneyim eksikliğinin olduğu söylenebilir. Öğrencilerin yapılandırılmamıs ve basit problem kurmaya meyilli olmalarının öğrenim yaşantılarından kaynaklandığı düşünülebilir.

Mevcut araştırmanın sonuçlarına göre, öğrenciler sırasıyla en çok durum 4 ve durum 1 için problem kurmakta zorlanmışlardır. Dördüncü durumda esas bileşeninin eksik olduğu, matematiksel olarak veri ve bilgi içeren durumlar verilmiş ve bunları kullanarak problem kurmaları istenmiştir. Bu durum için problem kuran öğrencilerden çok azının verilen verilerin hepsini kullanarak problem kurdukları tespit edilmiştir. Problem oluşturabilen öğrencilerin çoğunluğunun veriyi eksik kullandığı, konuyu farklılaştırdığı ya da yeni veri eklemiş olduğu görülmüştür. $\mathrm{Bu}$ çalışmanın sonuçlarından farklı olarak Tertemiz ve Sulak (2013) ilköğretim beşinci sınıf öğrencileri ile yaptıkları çalışmada öğrencilerin çoğunun problem kurarken koşulları ve konuyu değiştirmeyip verilen verilerin değerlerini değiştirme yönünde olduğunu ortaya koymuşlardır. Yine bu çalışmada durum 1'de ise öğrencilerin verilen açık uçlu problem ifadesini değiştirerek, onun bir tür uyarlamasını yapmaları beklenmektedir. Öğrencilerin durum

1 'de verdikleri yanıtlar incelendiğinde yarısının problem kurabildiği belirlenmiş ve problem kurabilen öğrencilerin tamamının veriler veya konu üzerinde değişiklik yaptığı görülmüştür. $\mathrm{Bu}$ sonucu ortaya koyan nedenlerden biri du- rumun veriliş şekli olabilir çünkü birinci durumda öğrencilerden problemi değiştirerek yeni bir problem kurmaları beklenmektedir. $\mathrm{Bu}$ değişikliği de öğrenciler konu ve veri değişikliği olarak algılamış olabilirler. Benzer sonuç dördüncü durum içinde geçerli olmasına rağmen birinci ve dördüncü durumların yapısı birbirinden farklılık göstermektedir.

Özetle araştırmada öğrencilerin, kendilerine yöneltilen dört farklı durumdan ikisinde daha fazla zorlandıkları tespit edilmiştir. Bu durumlardan biri, verilen açı uçlu problemin ifadesini değiştirerek, onun bir tür uyarlaması olan bir problem ortaya atılması iken, diğeri esas bileşeninin eksik olduğu, matematiksel olarak veri ve bilgi içeren durumların kullanıldığı problemlerdir. Öğrencilerin analitik düşünme ve akıl yürütme becerilerinin yeterince gelişmemiş olması ve matematik dilini kullanmakta zorlanıyor olmaları bu sonuca neden olmuş olabilir. Korkmaz ve Gür (2006) de yaptıkları çalışmada matematik öğretmeni adaylarının matematiksel düşünme ve akıl yürütmede beklentileri sağlayamadıklarını ve ayrıca ürettikleri problemlerde açık uçlu problemlere nadiren yer verdiklerini ortaya koymuşlardır.

\section{5 ÖNERILLER}

Araştırmanın sonuçlarından hareketle şu önerilerde bulunulabilir: Öğrenciler işlem ve sayı içeren durumlara ilişkin problemler kurabilmişler ancak analitik düşünme ve akıl yürütme becerilerini kullanmaları gereken durumlarda problem niteliği taşımayan yanıtlar da vermişlerdir. Aynı zamanda öğrencilerin matematiksel durumları düzgün bir şekilde yazılı olarak ifade edemedikleri de görülmektedir. Bu nedenle öğrencilerin lisansta aldıkları derslerde matematiksel ifade becerile- 
rinin geliştirilmesine yönelik çalışmalara yer verilmesi önerilebilir.

Araştırmanın katılımcılarının pedagojik formasyon eğitimi alan matematik öğretmeni adayı oldukları göz önünde bulundurulduğunda, onlarda problem çözme ve problem kurma becerilerinin gelişmiş olması beklenmektedir. Aldıkları pedagojik formasyon eğitimi ise "alan eğitimi" dersi olarak sadece "Özel Öğretim Yöntemleri”, “Öğretim Teknolojileri ve Materyal Tasarımı" ve "Öğretmenlik Uygulaması" derslerini içermektedir. Dolayısıyla problem kurma becerisi kazandıracak eğitimin verilebilmesi için bu derslerin yeterli olmadığ düşünüldüğünde, yeni derslerin eklenmesi ve buna bağlı olarak da pedagojik formasyon eğitiminin süresinin uzatılması önerilebilir.

Pedagojik formasyon alan matematik bölümü öğrencilerinin problem kurma teknikleri bu çalışma ile ortaya konulmuştur. Ancak kurdukları problemlerin zorluk düzeyleri veya ortaöğretim kazanımlarına uygunluğu dikkate alınmamıştır. İlerde yapılacak nitel çalışmalar ile öğretmen adaylarının kurdukları problemlerin zorluk düzeyleri veya kazanımlara uygunluğu irdelenebilir.

\section{Kaynakça}

Abramovich, S. (2014). Revisiting Mathematical Problem Solving and Posing in The Digital Era: Toward Pedagogically Sound Uses of Modern Technology. International Journal of Mathematical Education in Science and Technology, 45(7), 1034-1052.

Akay, H. (2006). Problem Kurma Yaklaşımı ile Yapılan Matematik Öğretiminin Öğrencilerin Akademik Başarısı, Problem Çözme Becerisi ve Yaratıcılı̆̆ı Üzerindeki Etkisinin İncelenmesi. Gazi Üniversitesi, Eğitim Bilimleri Enstitüsü, Doktora Tezi, Ankara.

Akay, H., Soybaş, D. ve Argün, Z. (2006). Problem Kurma Deneyimleri ve Matematik Öğretiminde AçıkUçlu Soruların Kullanımı. Kastamonu Ĕ̆itim Dergisi, 14(1), 129-146.

Albayrak, M. (2000). İlköğretimde Matematik ve Öğretimi. 2. Baskı, Ankara: Aşık Matbaası. Arıkan, E. E. ve Ünal, H. (2015). An Investigation of Eighth Grade Students' Problem Posing Skills (Turkey Sample). International Journal of Research in Education and Science (IJRES), 1(1), 23-30.

Ball, D. L., Thames, M. H. ve Phelps, G. (2008). Content Knowledge for Teaching: What Makes it Special? Journal of Teacher Education, 59(5), 389-407.

Ball, D.L., Lubienski, S.T. ve Mewborn, D.S. (2001). Research on Teaching Mathematics: The Unsolved Problem of Teachers' Mathematical Knowledge. In V. Richardson (Ed.), Handbook of research on teaching (4th ed.) (s. 433-456). New York: Macmillan.

Bunar, N. (2011). Altıncı Sını Öğrencilerinin Kümeler, Kesirler ve Dört İşlem Konularında Problem Kurma ve Çözme Becerileri. Afyon Kocatepe Üniversitesi, Sosyal Bilimler Enstitüsü, Yüksek Lisans Tezi, Afyonkarahisar.

Büyüköztürk, Ş., Kılıç Çakmak, E., Akgün, Ö. E., Karadeniz, Ş. ve Demirel, F. (2009). Bilimsel Araştırma Yöntemleri. Ankara: Pegem Akademi.

Cankoy, O. ve Darbaz, S. (2010). Problem Kurma Temelli Problem Çözme Öğretiminin Problemi Anlama Başarısına Etkisi. Hacettepe Üniversitesi Ĕ̆itim Fakültesi Dergisi, 38, 11-24. 
Chen, L., Dooren, W.V., Chen, Q. ve Verschaffel, L. (2011). An Investigation on Chinese Teachers' Realistic Problem Posing and Problem Solving Ability and Beliefs. International Journal of Science and Mathematics Education, 9, 919-948.

Dede, Y. ve Yaman, S. (2005). Matematik Öğretmen Adaylarının Matematiksel Problem Kurma ve Problem Çözme Becerilerinin Belirlenmesi. Eurasian Journal of Educational Research, 18, 236-252.

Demir, B. B. (2005). Problem Kurarak Ders İşleniş Yönteminin Öğrencinin Olasıllk Başarısına Etkisi ve Olasılı̆ga Yönelik Tutumuna Etkisi. Ortadoğu Teknik Üniversitesi, Yüksek Lisans Tezi, Ankara.

Dursun, Ş. ve Dede, Y. (2004). Öğrencilerin Matematikte Başarısını Etkileyen Faktörler: Matematik Öğretmenlerinin Görüşleri Bakımından. GÜ, Gazi Ĕ̆itim Fakültesi Dergisi, 24(2), 217-230.

Ersoy, Y. (2004). Problem Kurma ve Çözme Yaklaşımlı Matematik Öğretimi Yönünde Yenilik Hareketleri. Matematikçiler Derneği Bilim Köşesi, [Online]:http://www.matder.org.tr/ adresinden erişildi.

Gonzales, N. A. (1998). A Blueprint for Problem Posing. School Science \& Mathematics, 9(8), 448-456.

Işık, A., Çiltaş, A. ve Kar, T. (2012). Problem Kurma Temelli Öğretimin Farklı Sayı Algılamasına Sahip 6. Sınıf Öğrencilerin Problem Çözme Başarılarına Etkisi. Pegem Journal of Education and Instruction, $4,71-80$.

Işık, A., Işık, C. ve Kar, T. (2011). Matematik Öğretmeni Adaylarının Sözel ve Görsel Temsillere Yönelik Kurdukları Problemlerin Analizi. Pamukkale Üniversitesi Ĕ̆itim Fakültesi Dergisi, 30, 39-49.

Işık, C. ve Kar, T. (2012). Sınıf Öğretmeni Adaylarının Problem Kurma Becerileri. Mehmet Akif Ersoy Üniversitesi Ĕ̆itim Fakültesi Dergisi, 12(23), 190-214.

Kar, T. (2014). Ortaokul Matematik Öğretmenlerinin Öğretim İçin Matematiksel Bilgisinin Problem Kurma Bağlamında İncelenmesi: Kesirlerle Toplama İşlemi Örneği. Atatürk Üniversitesi, Eğitim Bilimleri Enstitüsü, Doktora Tezi, Erzurum.

Kar, T. ve Işık, A. (2015). Ortaokul Matematik Öğretmenlerinin Kesirlerle Çıkarma İşlemine Yönelik Problem Kurma Becerilerinin İncelenmesi. Dicle Üniversitesi Ziya Gökalp Ĕ̆itim Fakültesi Dergisi, 24, 243-276.

Kılıç, Ç. (2011). İlköğretim Matematik Dersi (1-5 Sınıflar) Öğretim Programında Yer Alan Problem Kurma Çalışmalarının İncelenmesi. Mersin Üniversitesi Eğitim Fakültesi Dergisi, 7(2), 54-65.

Kılıç, Ç. (2013). Sınıf Öğretmeni Adaylarının Farklı Problem Kurma Durumlarında Sergilemiş Oldukları Performansın Belirlenmesi. Kuram ve Uygulamada Eğitim Bilimleri, 13(2), 1195-1211.

Kılıç, Ç. (2014). Sınıf Öğretmenlerinin Problem Kurmayı Algılayış Biçimlerinin Belirlenmesi. Kastamonu Ĕ̆itim Dergisi, 22(1), 203-214.

Kılıç, Ç. ve İncikabı, L. (2013). Öğretmenlerin Problem Kurma ile İlgili Öz-Yeterlik İnançlarının Belirlenmesine Yönelik Ölçek Geliştirme Çalışması. Dumlupınar Üniversitesi Sosyal Bilimler Dergisi, 35, 223-234.

Kırnap-Dönmez, S.M. (2014). Illköğretim Matematik Öğretmen Adaylarının Problem Kurma Becerilerinin İncelenmesi. Erciyes Üniversitesi, Eğitim Bilimleri Enstitüsü, Yüksek Lisans Tezi, Kayseri. 
Kojima, K., Miwa, K. ve Matsui, T.(2015). Experimental Study of Learning Support Through Examples in Mathematical Problem Posing. Research and Practice in Techology Enhanced Learning, 10(1), 1-18.

Korkmaz, E. ve Gür, H. (2006). Öğretmen Adaylarının Problem Kurma Becerilerinin Belirlenmesi. BAÜ Fen Bilimleri Enstitüsü Dergisi, 8(1), 64-74.

Korkut, F. (2002). Lise Öğrencilerinin Problem Çözme Becerileri. Hacettepe Üniversitesi Ĕ̆itim Fakültesi Dergisi, 22, 177-184.

Lavy, I. \& Bershadsky, I. (2003). Problem Posing Via “What if Not?" Strategy in Solid Geometry-A Case Study. The Journal of Mathematical Behavior, 22(4), 369-387.

Miles, B. M. ve Huberman, A. M. (1994). Qualitative Data Analvsis (2nd ed.). London: Sage Publisher.

Milli Eğitim Bakanlığı, Talim ve Terbiye Kurulu Başkanlığı (MEB) (2005). İköğretim Matematik (6., 7. ve 8.) Stmıflar Dersi Öğretim Programı, Ankara.

Milli Eğitim Bakanlığı, Talim ve Terbiye Kurulu Başkanlığı (MEB) (2013a). Ortaokul Matematik Dersi (5, 6, 7 ve 8 Sinıflar) Öğretim Programı, Ankara.

Milli Eğitim Bakanlığı, Talim ve Terbiye Kurulu Başkanlığı (MEB) (2013b). Ortaöğretim Matematik Dersi (9, 10, 11, 12. Sinıflar) Öğretim Programı, Ankara.

Polya, G. (1997). Nasıl çözmeli? Matematikte yeni bir boyut. (Çev: F. Halatçı). İstanbul: Sistem Yayıncılık.

Savaş, E., Taş, S. ve Duru, A. (2010). Matematikte Öğrenci Başarısını Etkileyen Faktörler. İnönü Üniversitesi Eğitim Fakültesi Dergisi, 11(1), 113-132.

Stoyanova, E. (2003). Extending Students' Understanding of Mathematics Problem Solving via Problem Posing. Australian Mathematics Teacher, 59(2), 32-40.

Sünbül, A.M. (1996). Öğretmen Niteliği ve Öğretimdeki Rolleri. Kuram ve Uygulamada Eğitim Yönetimi Dergisi, 2(1), 597-607.

Tertemiz, N. ve Sulak, S.E. (2013). İlköğretim Beşinci Sınıf Öğrencilerinin Problem Kurma Becerilerinin İncelenmesi. İlköğretim Online, 12(3), 713-729.

Toluk-Uçar, Z. (2009). Developing Pre-Service Teachers Understanding of Fractions Through Problem Posing. Teaching and Teacher Education, 25(1), 166-175.

Turhan, B. (2011). Problem Kurma Yaklaşımı ile Gerçekleştirilen Matematik Öğretiminin İlköğretim 6. Sımıf Öğrencilerinin Problem Çözme Başarıları, Problem Kurma Becerileri ve Matematiğe Yönelik Görü̈slerine Etkisinin İncelenmesi. Anadolu Üniversitesi, Eğitim Bilimleri Enstitüsü, Yüksek Lisans Tezi, Eskişehir.

Turhan, B. ve Güven, M. (2014). Problem Kurma Yaklaşımıla Gerçekleştirilen Matematik Öğretiminin Problem Çözme Başarısı, Problem Kurma Becerisi ve Matematiğe Yönelik Görüşlere Etkisi. Çukurova Üniversitesi Ĕ̆itim Fakültesi Dergisi, 43(2), 217-234.

Yenilmez, K. ve Ev-Çimen, E. (2014). Matematik Öğretmeni Adaylarının “Örnek, Alıştırma, Problem” Oluşturma Çalışmalarının İncelenmesi. Ĕğitim ve Öğretim Araştırmaları Dergisi, 3(3), 76-84. 
64 | SAÜ Eğitim Bilimleri Enstitüsü

Yıldız, A. ve Baltacı, S. (2015). İlköğretim Matematik Öğretmen Adaylarının Problem Kurma Etkinlikleri ile Olasılı̆ga Yönelik Bilgilerinin İncelenmesi. Ahi Evran Üniversitesi Kırşehir Eğitim Fakültesi Dergisi (KEFAD), 16(1), 201-213.

YÖK, 2015. Pedagojik Formasyon Eğitimi Sertifika Programına İlişkin Usul ve Esaslar, http://www.yok.gov.tr/web/guest/icerik/journal_content/56_INSTANCE_rEHF8BIsfYRx/10279/7052802 adresinden erişildi. 


\section{Extended Summary}

Problem posing, in turn, entails the discovery of new questions to be investigated or discovered about a given case (Akay, 2006). In this context, the individuals with problem-posing skills can, using the available information, produce new information, and formulate their own problems (Turhan and Güven, 2014). The designing of applicable learning-teaching processes by the teachers is particularly crucial in terms of instilling the problem-posing skills in the students. Against this background, this study aims to analyze the problem posing skills among mathematics department students who receive pedagogical formation training.

The study was carried out employing a case study methodology, with a descriptive perspective. The participants comprise 46 mathematics department students who receive pedagogical formation training at a respected faculty of education. The data was gathered using the "Mathematics Teaching and Problem Posing" test developed by Korkmaz and Gür (2006). The test covers 4 distinct cases. The first one entails the modification of a given open-ended problem statement to develop an adaptation of it. The second case is about trying posing problems using the specified numbers and operations. In the third case, the prospective teachers were asked to pose solvable problems, using a given set of mathematical equations. Finally, the participants were given mathematical input where the pivotal element is missing, and asked to pose a problem using the information available to them. The data underwent content analysis, and were assigned flags of 'problem', 'not a problem', 'no answer' accordingly, upon the review of each problem posed by the participants.

The findings may be summarized as follows: The students were able to pose problems relatively easily for some of the 4 cases, while for others, they experienced significant difficulties. 23 students were able to pose problems for the first case, while 14 left the question without an answer, and the problem posed by 9 were unacceptable. In the second case, 36 students were able to pose problems, while 3 posed none, and 7 posed incorrect ones. In the third case, 44 students successfully posed problems, 1 did not pose any, and 1 posed an incorrect one. For the fourth case, 21 students were able to pose problems, 9 left the question unanswered, and 16 posed incorrect problems.

The majority of the students were relatively successful in posing problems by using mathematical equations in addition to the given set of numbers and operations. However, in the cases where they were required to modify a given open-ended problem statement so as to develop an adaptation of it, or to pose a problem with a set of mathematical data and information with the pivotal element missing, they were less successful. The underlying cause may be low level of analytical thought and reasoning skills development and difficulties in using the language of mathematics among the students. These findings may lead to a recommendation to add new courses to the pedagogical formation training programs in order to provide the required skills, and to extend the length of the formation training accordingly. 